\title{
Tyrosine-Protein Kinase RYK
}

National Cancer Institute

\section{Source}

National Cancer Institute. Tyrosine-Protein Kinase RYK. NCI Thesaurus. Code C29920.

Tyrosine-protein kinase RYK (604 aa, $\sim 68 \mathrm{kDa}$ ) is encoded by the human RYK gene. This protein is involved in receptor signaling, tyrosine phosphorylation and protein-protein interactions. 